Article

\title{
In Vitro and Cryobiotechnology Approaches to Safeguard Lupinus rivularis Douglas ex Lindl., an Endangered Plant in Canada
}

\author{
Elena V. Popova ${ }^{1,2}$, Mukund R. Shukla ${ }^{1}\left(\mathbb{D}\right.$, Terry McIntosh ${ }^{3}$ and Praveen K. Saxena ${ }^{1, *(D)}$ \\ 1 Department of Plant Agriculture, Gosling Research Institute for Plant Preservation, University of Guelph, \\ Guelph, ON N1G 2W1, Canada; elena_aygol@hotmail.com (E.V.P.); mshukla@uoguelph.ca (M.R.S.) \\ 2 K.A. Timiryazev Institute of Plant Physiology of Russian Academy of Sciences, Moscow 127276, Russia \\ 3 Botany Department, University of British Columbia, Vancouver, BC V6T 1Z4, Canada; ttmcintosh@shaw.ca \\ * Correspondence: psaxena@uoguelph.ca; Tel.: +1-519-824-4120 (ext. 52495)
}

Citation: Popova, E.V.; Shukla, M.R.; McIntosh, T.; Saxena, P.K. In Vitro and Cryobiotechnology Approaches to Safeguard Lupinus rivularis Douglas ex Lindl., an Endangered Plant in Canada. Agronomy 2021, 11, 37. https://dx.doi.org/10.3390/ agronomy11010037

Received: 3 November 2020 Accepted: 22 December 2020 Published: 26 December 2020

Publisher's Note: MDPI stays neutral with regard to jurisdictional claims in published maps and institutional affiliations.

Copyright: () 2020 by the authors. Licensee MDPI, Basel, Switzerland. This article is an open access article distributed under the terms and conditions of the Creative Commons Attribution (CC BY) license (https: / / creativecommons.org/ licenses/by/4.0/).

\begin{abstract}
Conservation of threatened flora in genetic collections ex situ using in vitro culture and cryopreservation is receiving an increasing recognition as a complementary strategy to in situ conservation in natural habitats. The present study is focused on an integrated approach which involves conservation and propagation, emphasizing the usefulness of cryopreservation techniques for germplasm conservation of streambank lupine (Lupinus rivularis Douglas ex Lindl.), an endangered species in Canada. This included in vitro seed germination on Murashige and Skoog basal medium supplemented with $1 \mu \mathrm{M}$ thidiazuron to induce multiple shoot formation, micropropagation on a medium with $5 \mu \mathrm{M}$ benzylaminopurine, and in vitro rooting on medium with $20.0 \mu \mathrm{M}$ indole-3butyric acid. Cryopreservation of seeds and shoot tips of in vitro grown plants was successful with over $60 \%$ seed germination and $62 \%$ regrowth of cryopreserved shoot tips, respectively. Plants developed from cryopreserved seeds had chlorophyll contents in leaves and the growth characteristics including the development of inflorescence, similar to plants raised from non-cryopreserved seeds. These results provide further evidence that the combination of micropropagation with cryopreservation of seeds and vegetative parts may effectively facilitate long-term preservation of L. rivularis and other endangered species.
\end{abstract}

Keywords: biobanking; conservation; cryopreservation; endangered species; lupine; micropropagation

\section{Introduction}

Lupinus rivularis Dougl. ex. Lindl., or streambank lupine, is a perennial, primarily herbaceous species endemic to Western North America. The plants reach heights of 4-6 dm with lavender flowers that bloom from May until September. The species is found globally only in a narrow strand along the North American Pacific Coast, from NorthWestern California (USA) to SouthWestern British Columbia (Canada) [1]. In 2002, during the assessment of the Committee on the Status of Endangered Wildlife in Canada (COSEWIC), only six populations of L. rivularis were found in Canada: one on Southern Vancouver Island, and five in the lower Fraser Valley with a population size range of one to 100 plants [2]. In 2014, eight populations of the species were confirmed with one to 600 plants [3]. However, it was alarming that, since the first assessment in 2002, many of the populations have decreased in flowering plant numbers and areal extent [3]. All Canadian populations of $L$. rivularis are at high risk from habitat destruction, herbicide spraying, predation by slugs, climatic changes, and genetic swamping through hybridization with other lupine species [2]. In addition, like all other lupines, it runs the risk of being picked for the beauty of its flowers. Most of the populations of L. rivularis occur on railway beds, dykes, and along roadsides in private industrial lands where disturbances are regular while long-term protective measures are difficult to implement [4]. The COSEWIC 2002 report 
contains a strong statement that "the entire species could be eliminated within its Canadian range with very little effort" [2]. Based on these assessments, streambank lupine was designated as "Endangered" by COSEWIC and is listed in Schedule 1 of the Species at Risk Act (SARA) in Canada. In British Columbia, streambank lupine is ranked S1 (critically imperiled) by the Conservation Data Centre and is on the provincial Red list (BCCDC 2020). The recovery plan for L. rivularis recommends, among other measures, a long-term protection for extant populations and habitats, addressing knowledge gaps relating to species' biology, and clarifying and mitigating threats [3].

Ex situ conservation of threatened species in genetic collections including botanical gardens, seed banks, DNA banks, in vitro collections and cryobanks is a complementary strategy to in situ conservation in natural habitats [5,6]. In Vitro propagation and cryopreservation are being increasingly utilized to support conservation of wild flora and endangered plant species worldwide [6,7]. In Vitro propagated plants are suitable for medium-term conservation purposes and to raise plant material for restoration of dwindling populations of threatened species [8] as demonstrated for Castilleja levisecta and Cirsium hillii $[9,10]$. Cryopreservation is the process by which living tissues are conserved in a viable state in liquid nitrogen $\left(-196^{\circ} \mathrm{C}\right)$. Seeds are the preferred option for cryobanking native plant species due to their natural ability to withstand drying and the large diversity of genotypes that can be stored in minimal space [11]. Cryopreservation of in vitro shoot tips or axillary buds help in situations when only few plants remain alive in nature, seeds are desiccation-sensitive or hard to germinate, and for preserving elite germplasm [5,12-15]. L. rivularis reproduces primarily by seeds that are listed as orthodox in the Seed Information Database of Kew Botanical Garden [16] and require abrasion or decomposition of seed coats for germination to occur [2]. Darris and YoungMathews found that lupine seeds have physical dormancy and should be mechanically scarified or soaked in hot water to enhance germination [17]. In Vitro seed germination and tissue culture propagation of several lupine species that are used as forage crops have been reported [18-21]. However, to the best of our knowledge, in vitro propagation and cryopreservation of $L$. rivularis has not been documented.

In this study, we describe an effective ex situ conservation approach referred to as the conservation, propagation and redistribution (CPR) model [10], which combines in vitro technologies to multiply L. rivularis plants for redistribution projects while the species gene-pool can be safely cryopreserved for the long-term.

\section{Materials and Methods}

\subsection{Seed Germination In Vitro and Multiple Shoot Induction}

Mature seeds of $L$. rivularis were provided by the Streambank Lupine Recovery Team in British Columbia, from two consequent years and designated respectively as Seed lots 1 and 2. Seeds were stored at $4{ }^{\circ} \mathrm{C}$ in the dark for one (Seed lot 2) or two (Seed lot 1) years before using them for the experiments. Seeds were surface sterilized with $4 \%$ commercial bleach (Clorox ${ }^{\circledR} ; 5.4 \%$ sodium hypochlorite) for $1 \mathrm{~h}$, followed by $20 \%$ bleach (Clorox ${ }^{\circledR}$; $5.4 \%$ sodium hypochlorite) for $15 \mathrm{~min}$, and rinsed with autoclaved deionized water four times, each wash lasting $3 \mathrm{~min}$. Sterile seeds were germinated in Magenta GA7 culture vessels filled with $50 \mathrm{~mL}$ of semisolid culture medium containing MS (Murashige and Skoog) [22] basal salts and vitamins (PhytoTechnology Laboratories, Kansas City, KS, USA) with $3 \%$ sucrose and $2.2 \mathrm{~g} \mathrm{~L}^{-1}$ Phytagel $^{\mathrm{TM}}$ (Sigma-Aldrich, Oakville, ON, Canada) and the $\mathrm{pH}$ adjusted to 5.7. Medium was autoclaved for $20 \mathrm{~min}$ at $121^{\circ} \mathrm{C}$ and $118 \mathrm{kPa}$ and allowed to cool in sterile conditions. To stimulate seed germination and induce multiple shoot formation, various concentrations $(0,1,5,10$ and $20 \mu \mathrm{M})$ of thidiazuron (TDZ; Caisson, Logan, UT, USA) were added to the basal medium. Cultures were kept in a growth chamber at $25^{\circ} \mathrm{C} \pm 2{ }^{\circ} \mathrm{C}$ in the dark. Seed germination percentage, percentage of seeds with multiple shoot formation and the number of shoots developed per germinated seed were recorded after 35 days of culture. However, most multiple shoots formed from seed lot 2 showed necrosis and died within a few weeks. Therefore, the number of shoots per germinated seed 
was counted only for seed lot 1 . Four replications were used for each treatment and each replication contained ten seeds. In Vitro shoots developed from seeds were separated and individually subcultured in Magenta GA7 culture vessels on MS basal medium without growth regulators.

\subsection{Shoot Multiplication In Vitro}

One-month-old in vitro shoots, approximately $10 \mathrm{~cm}$ in length, developed from seeds on TDZ-free basal medium were used to prepare the explants for shoot multiplication experiments. Three types of explants, approximately $1 \mathrm{~cm}$ in length, were used: "apical sections" with an apical shoot tip cut from the top of the plant, "middle stem sections" with one axillary bud extracted at the level of the 4 th node (the middle of the plant height) and "basal stem sections" with one axillary bud extracted from the bottom of the plant (the last node). Each explant was placed in individual glass test tube filled with $10 \mathrm{~mL}$ of MS basal medium with 0, 2, 5, 10 or $20 \mu \mathrm{M}$ 6-benzylaminopurine (BA; PhytoTechnology). Ten individual explants of each type were used per treatment. All cultures were kept in a growth room at $25{ }^{\circ} \mathrm{C} \pm 2{ }^{\circ} \mathrm{C}$ under a $16 \mathrm{~h}$ photoperiod provided by cool white fluorescent lamps (Osram Sylvania Ltd., Mississauga, ON, Canada) at a light intensity of $35-40 \mu \mathrm{mol} \mathrm{m}^{-2} \mathrm{~s}^{-1}$. After 30 days, number of shoots developed per explant and shoot length were recorded.

\subsection{In Vitro Rooting and Acclimatization}

The effects of indole-3-butyric acid (IBA; PhytoTechnology) was evaluated on fourweek-old shoots from MS basal medium with $5 \mu \mathrm{M}$ BA, approximately $2 \mathrm{~cm}$ in length, to optimize in vitro root induction. Different concentrations of IBA at $0,5,10,20$ and $50 \mu \mathrm{M}$ were individually added to the MS basal medium with vitamins, $3 \%$ sucrose and $2.2 \mathrm{~g} \mathrm{~L}^{-1}$ Phytagel $^{\mathrm{TM}}$ with $\mathrm{pH}$ adjusted to 5.7. A single shoot was placed in a Magenta GA7 vessel and 30 shoots were used per treatment. Three replications were used for each treatment and each replication contained ten shoots. The number of roots per shoot was recorded after forty days of culture.

To determine survival in the greenhouse, all plantlets were rinsed with deionized water to remove any excess medium and then transferred to 18-cell trays containing soil mix, Sunshine Mix \#4 (Sun Gro Horticulture Canada Ltd., Vancouver, BC, Canada). Trays were placed in the mist bed for ten days and then transferred to greenhouse benches. The greenhouse compartment was programmed to have a constant temperature of $23^{\circ} \mathrm{C}$ during the day and $18{ }^{\circ} \mathrm{C}$ at night with a $16 \mathrm{~h}$ photoperiod, and a light intensity of $250 \mu \mathrm{mol} \mathrm{m} \mathrm{m}^{-2} \mathrm{~s}^{-1}$. Survival percentage was recorded fifteen days after the plants had been transferred to the greenhouse.

\subsection{Seed Cryopreservation and Its Effect on Plant Development}

To investigate the impact of cryopreservation, seeds were sealed in $2 \mathrm{~mL}$ cryovials (ThermoScientific, Rochester, NY, USA) and stored in liquid nitrogen (LN) Dewar for 24-48 h. Cryovials were then placed in a $40{ }^{\circ} \mathrm{C}$ water bath for $90 \mathrm{~s}$ for rewarming. Control and cryopreserved seeds were sterilized as described above and germinated on the double layer of moisturized filter paper in $9 \mathrm{~cm}$ Petri dishes in a growth chamber at $25^{\circ} \mathrm{C} \pm 2{ }^{\circ} \mathrm{C}$ under light conditions as described above. Alternatively, control and cryopreserved seeds were planted directly in Sunshine professional growing medium (Sun Gro Horticulture Canada Ltd., Vancouver, BC, Canada) and placed in the greenhouse as described above. Seed lot 2 was germinated only in a greenhouse due to small number of seeds available. Germination under greenhouse and in vitro conditions as described above was recorded at various intervals over 33 days. This experiment was performed in three replications, with each replication consisting of 20-36 seeds. After 3 months, seedlings developed in vitro were multiplied using the protocol developed in this study. Seedlings developed from seeds in the greenhouse were transferred to bigger pots in the same greenhouse. After 9 months, morphological characteristics of plants in the greenhouse such as number of fully developed leaves, number of branches, length of the longest branch 
and number of flower stalks were recorded using 40 plants for each treatment. The chlorophyll content of the leaves was estimated using a modulated ratio fluorescence chlorophyll fluorometer (CCM-300, Opti-Sciences, Hudson, NH, USA) based on the method described by Gitelson et al. [23]. Four measurements were taken from each plantlet to represent the chlorophyll content of each individual plantlet. The results are expressed as chlorophyll content $\left(\mathrm{mg} \mathrm{m}^{-2}\right)$ and reported as mean \pm standard error for 10 plants.

\subsection{Cryopreservation of Apical Shoot Tips}

Apical segments, ca. $15 \mathrm{~mm}$ in length, each including an apical shoot tip, were excised from in vitro shoots one month after the last subculture and placed on MS basal medium without growth regulators. After 7 days, apical shoot tips, $1.5 \mathrm{~mm}$, were excised and cryopreserved using a droplet-vitrification method modified according to Popova et al. [24]. Briefly, apical shoot tips were precultured in liquid MS medium with $0.3 \mathrm{M}$ sucrose for $24 \mathrm{~h}$, then osmoprotected in the solution C4-35\% (17.5\% glycerol and $17.5 \%$ sucrose, $w / v)$ for 20 min followed by treatment in vitrification solution A3 (37.5\% glycerol $+15 \%$ dimethylsulfoxide $(\mathrm{DMSO})+15 \%$ ethylene glycol $+22.5 \%$ sucrose, $w / v)$ on ice for $30 \mathrm{~min}$ [25] Each shoot tip was placed in an individual drop of ice-cold A3 onto a strip of aluminum foil $(6 \times 30 \mathrm{~mm}$; Western Plastics, Canada) that were quickly immersed in the liquid nitrogen (LN) for at least $1 \mathrm{~h}$. For rewarming, the foil strips were plunged in $20 \mathrm{ml}$ of preheated $\left(40{ }^{\circ} \mathrm{C}\right)$ unloading solution $(0.8 \mathrm{M}$ sucrose) for $30 \mathrm{~s}$, after which an equivalent volume of unloading solution was added at room temperature. Foils were removed with forceps, and shoot tips were kept in the solution for $30 \mathrm{~min}$ on a shaker $(90 \mathrm{rpm})$. Shoot tips were blotted dry on a sterile filter paper and cultured on MS basal medium with $1.0 \mu \mathrm{M}$ gibberellic acid $\left(\mathrm{GA}_{3}\right)$ using $9 \mathrm{~cm}$ Petri dishes for regrowth. Cultures were kept in darkness for the initial 5 days after rewarming and then moved to low light conditions $\left(5 \pm 2 \mu \mathrm{mol} \mathrm{m}^{-2} \mathrm{~s}^{-1}\right)$. Control shoot tips underwent the same treatments, except they were not immersed in LN. All solutions used for preculture, cryoprotection, and rewarming were prepared in MS basal medium with MS vitamins ( $\mathrm{pH}$ 5.7) and sterilized by filtering through 0.2 micron filters (Falcon, Durham, NC, USA). Shoot tips that developed into plantlets after 50 days were counted to assess regeneration. All treatments were performed in three independent replications, each containing at least 10 shoot tips.

\subsection{Statistical Analysis}

Data were analyzed by ANOVA, followed by the Duncan's Multiple Range Test (DMRT) at $p=0.05$ using SAS University edition 3.4 (SAS Institute Inc. Cary, NC, USA). All ANOVA results that were significant were subjected to the Tukey Test to determine which means were significantly different from each other. Values in the figures followed by different letters are significantly different $(p<0.05)$ and the data presented are the means \pm SEM.

\section{Results}

\subsection{Seed Germination In Vitro and Multiple Shoot Induction}

Seeds of both seed lots germinated in vitro with frequencies above $60 \%$ with no significant differences between the seed lots and TDZ concentrations in the medium (Figure 1A). In seed lot 1, germination on TDZ-containing medium was only $9 \%$ higher than on the control medium without TDZ. Germination of seed lot 2 increased from $63 \%$ on TDZ-free medium to $83-93 \%$ in the presence of 1,5, and $10 \mu \mathrm{M}$ TDZ but dropped to $60 \%$ at a higher concentration $(20.0 \mu \mathrm{M})$.

Seeds of both seed lots produced single shoots when germinating on TDZ-free medium while the presence of TDZ induced multiple shoot formation in both seed lots (Figure 1B). In Seed lot 1 , the highest frequency of multiple shoot formation $(>80 \%)$ was recorded on medium with 5-20 $\mu \mathrm{M}$ TDZ (Figures 1B and 2A). Average number of shoots developed from one seed increased with increasing TDZ concentration and was maximum at 10 and 
$20 \mu \mathrm{M}$ TDZ with $4.2-4.8$ shoots per seed (Figure 1C). In contrast, only $20-40 \%$ of seeds from Seed lot 2 showed multiple shoot formation in the presence of TDZ.

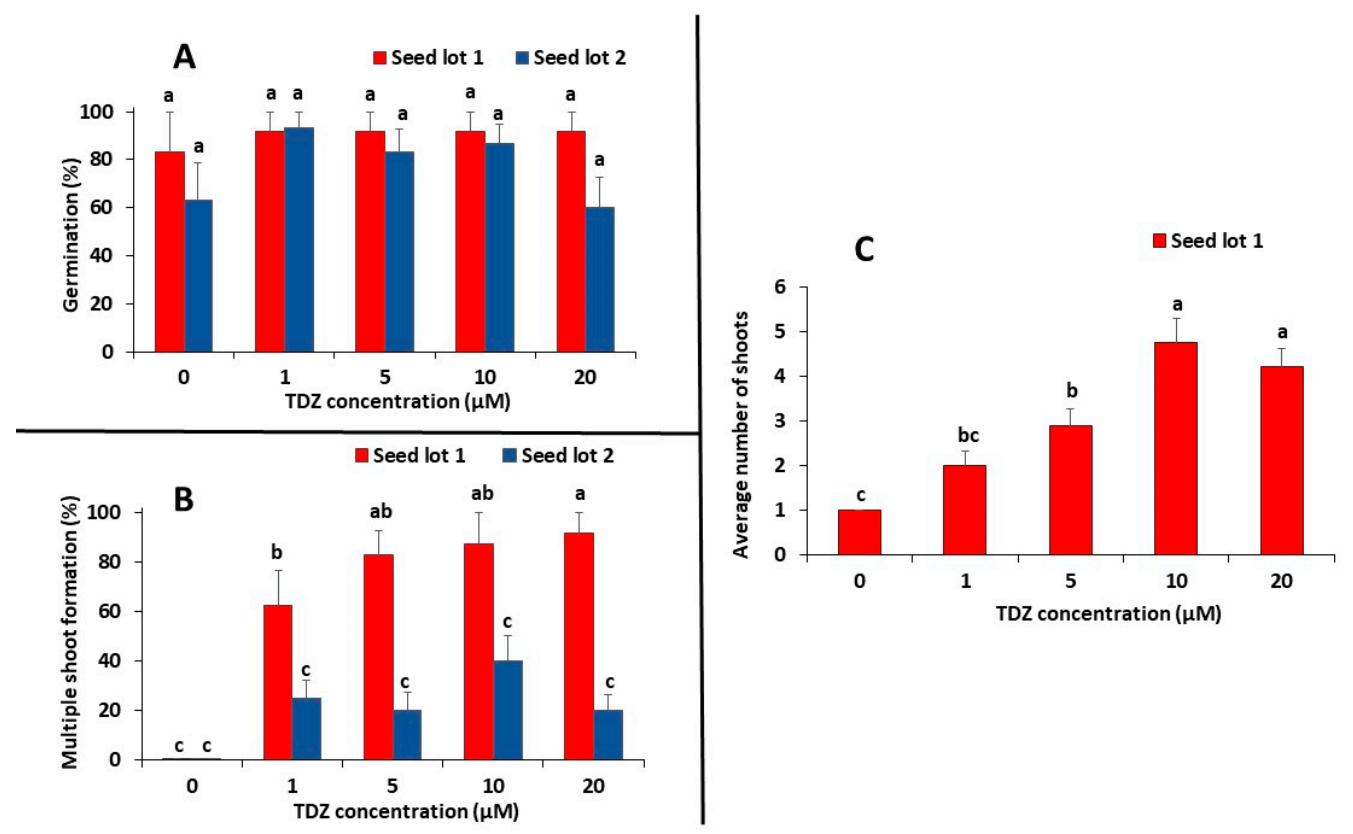

Figure 1. Effect of different thidiazuron (TDZ) concentrations $(0,1,5,10,20 \mu \mathrm{M})$ on seed germination (A), percentage of seeds with multiple shoot formation (B) and average number of shoots per germinated seed (C) of Lupinus rivularis for two different seed lots. Shoots formed from seed lot 2 showed necrosis and died within a few weeks. Data represents mean \pm standard error from four replications, 10 seeds per replication. Means followed by different letters are significantly different according to Tukey Test $(p<0.05)$.

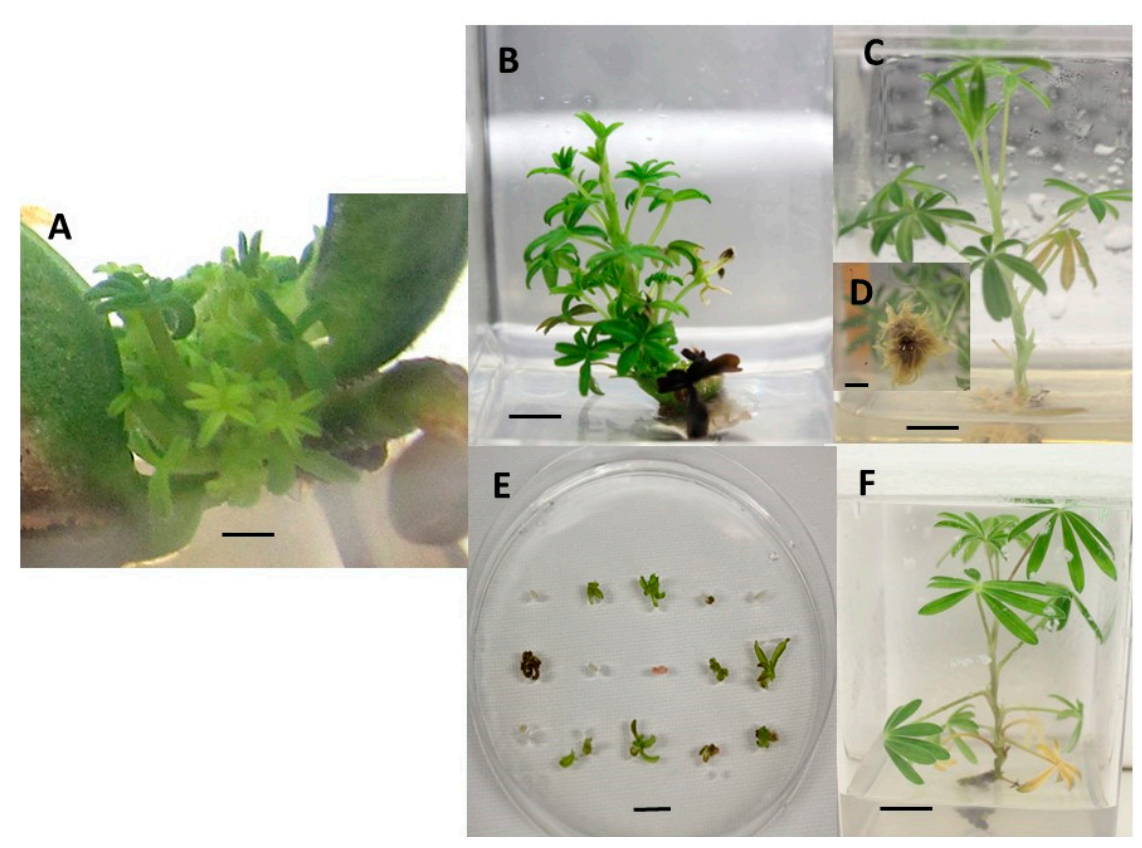

Figure 2. In Vitro culture of seeds, plants and cryopreserved shoot tips of Lupinus rivularis. Multiple shoot induction from seeds on medium with $10 \mu \mathrm{M}$ TDZ (A); In vitro plant developed from basal explant on medium with $5 \mu \mathrm{M}$ BA (B); Rooting of individual shoots subcultured on the medium with $20 \mu \mathrm{M}$ IBA (C,D); Survival of cryopreserved shoot tips, 30 days after cryopreservation (E); Plant regeneration from cryopreserved shoot tips, 6 months after cryopreservation (F). Bar in $\mathbf{A}-\mathbf{F}=1 \mathrm{~cm}$. 


\subsection{Shoot Multiplication In Vitro}

A significant difference for shoot development was observed between three types of explants. All explants extracted from the apical and basal parts of in vitro plants developed into normal single shoots on the basal medium without BA (Table 1). By contrast, only $30 \%$ of middle sections were capable for shoot formation without exogenous cytokinin (Table 1). When BA was added in culture medium, apical sections produced an average 2 to 3 shoots compared to 1-2 shoots developed from middle and basal explants (Table 1). Maximum number of shoots per explant (2.6-2.8) was recorded for apical explants cultured with 5 and $10 \mu \mathrm{M}$ BA and for basal sections cultured on the medium with $10 \mu \mathrm{M} \mathrm{BA}$. The length of new shoots developed from apical explants was significantly higher than in shoots formed from middle and basal explants (Table 1). Meanwhile, no significant influence of BA concentrations on shoot length was detected for explant type. Therefore, apical explants cultured on medium with $5 \mu \mathrm{M}$ BA were considered most suitable for micropropagation of L. rivularis (Figure 2B).

Table 1. Effect of BA $(0-20 \mu \mathrm{M})$ added to the culture medium and the explant type on explant response, average shoot number, and shoot height. Data represents mean from three replications and 10 explants per replication. Means marked by different letters in columns are significantly different according to the Tukey test $(p<0.05)$.

\begin{tabular}{|c|c|c|c|c|}
\hline $\begin{array}{c}\text { BA Concentration } \\
(\mu \mathrm{M})\end{array}$ & Explant Type & Explant Response (\%) & $\begin{array}{l}\text { Shoot Height } \\
(\mathrm{mm})\end{array}$ & Avg. nos. of Shoot/Explant \\
\hline \multirow{3}{*}{0} & Tip & 100 & $18.80^{a b c}$ & $1.0 \mathrm{de}$ \\
\hline & Mid & 30 & $1.34^{\mathrm{e}}$ & $0.3^{\mathrm{e}}$ \\
\hline & Base & 60 & 8.61 de & $1.2^{\text {bcde }}$ \\
\hline \multirow{3}{*}{2} & Tip & 100 & $20.94^{\mathrm{ab}}$ & $2.2^{\mathrm{abcd}}$ \\
\hline & Mid & 60 & $4.74 \mathrm{de}$ & 1.1 cde \\
\hline & Base & 80 & 7.97 de & $1.5^{\text {abcde }}$ \\
\hline \multirow{3}{*}{5} & Tip & 100 & $24.59^{\mathrm{a}}$ & $2.7^{a b}$ \\
\hline & Mid & 100 & $12.36^{\mathrm{bcd}}$ & 1.8 abcde \\
\hline & Base & 90 & $13.34^{\mathrm{bcd}}$ & $2.0^{\mathrm{abcd}}$ \\
\hline \multirow{3}{*}{10} & Tip & 100 & $19.66^{\mathrm{ab}}$ & $2.6^{\mathrm{abd}}$ \\
\hline & Mid & 90 & 9.69 cde & $2.0 \mathrm{abcd}$ \\
\hline & Base & 100 & $14.07^{\mathrm{bcd}}$ & $2.8^{\mathrm{a}}$ \\
\hline \multirow{3}{*}{20} & Tip & 100 & $18.66^{\mathrm{abc}}$ & $2.1^{\mathrm{abcd}}$ \\
\hline & Mid & 80 & 9.74 cde & $1.6^{\text {abcde }}$ \\
\hline & Base & 70 & $10.02^{\text {cde }}$ & $1.0^{\mathrm{e}}$ \\
\hline
\end{tabular}

\subsection{In Vitro Rooting and Acclimatization}

Root induction was observed only in the treatment with $20.0 \mu \mathrm{M}$ IBA (Figure 2C,D), with $45 \%$ of the shoots showing the response. The average number of roots and root length were observed to be 7 and $2.1 \mathrm{~cm}$, respectively, on the medium supplemented with $20.0 \mu \mathrm{M}$ IBA. However, callus formation was observed without rooting in other treatments, including the control. Normal shoot and root development was observed without callus formation in the treatment with $20.0 \mu \mathrm{M}$ IBA, and hence it was considered an optimal inductive stimulus for in vitro rooting. Nearly $80 \%$ rooted plantlets survived in the greenhouse following 10 days of conditioning in the mist bed. All shoots from different treatments, including the control, which failed to form roots and grow into plantlets did not survive after three weeks of transplanting in the greenhouse.

\subsection{Seed Cryopreservation and Its Effect on Plant Development}

Cryopreserved seeds from seed lot 1 germinated in the greenhouse $(62 \%)$ and in vitro (78\%) similar to non-cryopreserved seeds (Figure 3A). For Seed lot 2, the difference for germination was found to be non-significant for cryopreserved (71\%) and non-cryopreserved 
(58\%) seeds (Figure 3B). Germination events observed for seeds in the control and seeds exposed to liquid nitrogen were similar under the same germination conditions (Figure 3).
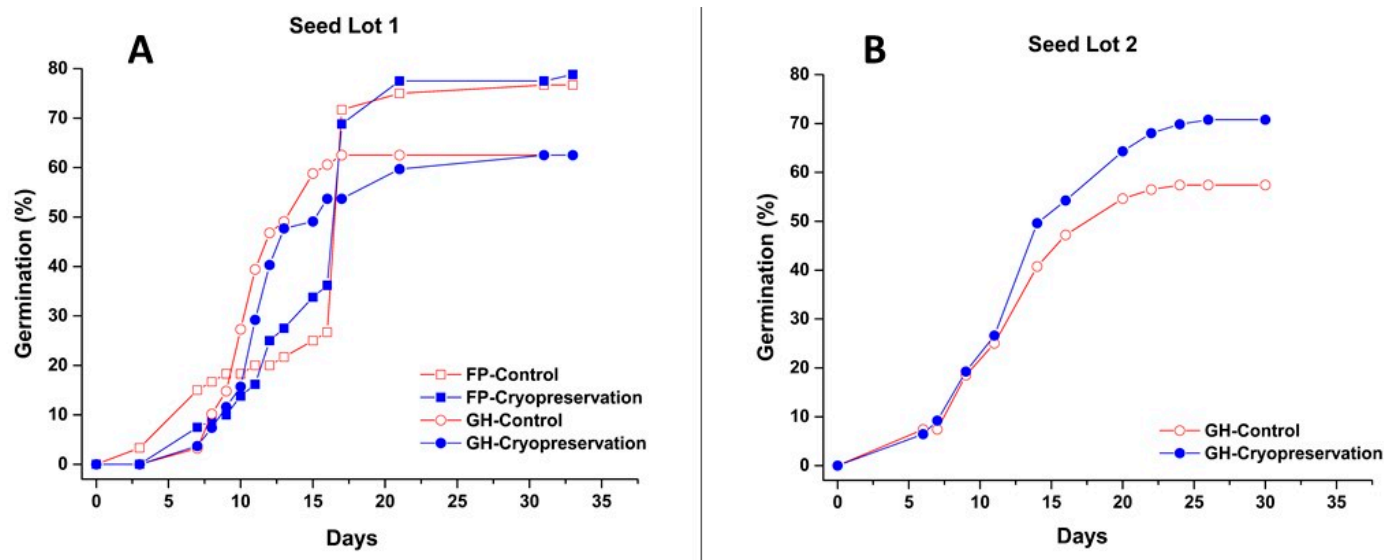

Figure 3. Germination percentage over 35 days under in vitro and greenhouse conditions for control and cryopreserved seeds of two different seed lots, seed lot 1 (A) and seed lot 2 (B) of Lupinus rivularis. FP-in vitro seed germination was performed on filter paper using $9 \mathrm{~cm}$ Petri dishes in the growth chamber; GH-seed germination was performed on soil substrate in the greenhouse.

All seedlings that emerged from control and cryopreserved seeds developed into normal plants (Figure 4A-D). There was no difference in the length of the longest branch and number of flower stalks among plants developed from control and cryopreserved seeds and between seed lots (Table 2). The only significant variation between plants from control and cryopreserved seeds was observed in the number of branches in Seed lot 2 . Number of fully developed leaves was significantly different between the seed lots 1 and 2 but it was not related to cryopreservation (Table 2). Chlorophyll content was slightly higher in leaves of plants grown from cryopreserved seeds in both of the lots, but this difference was not significant (Table 2).
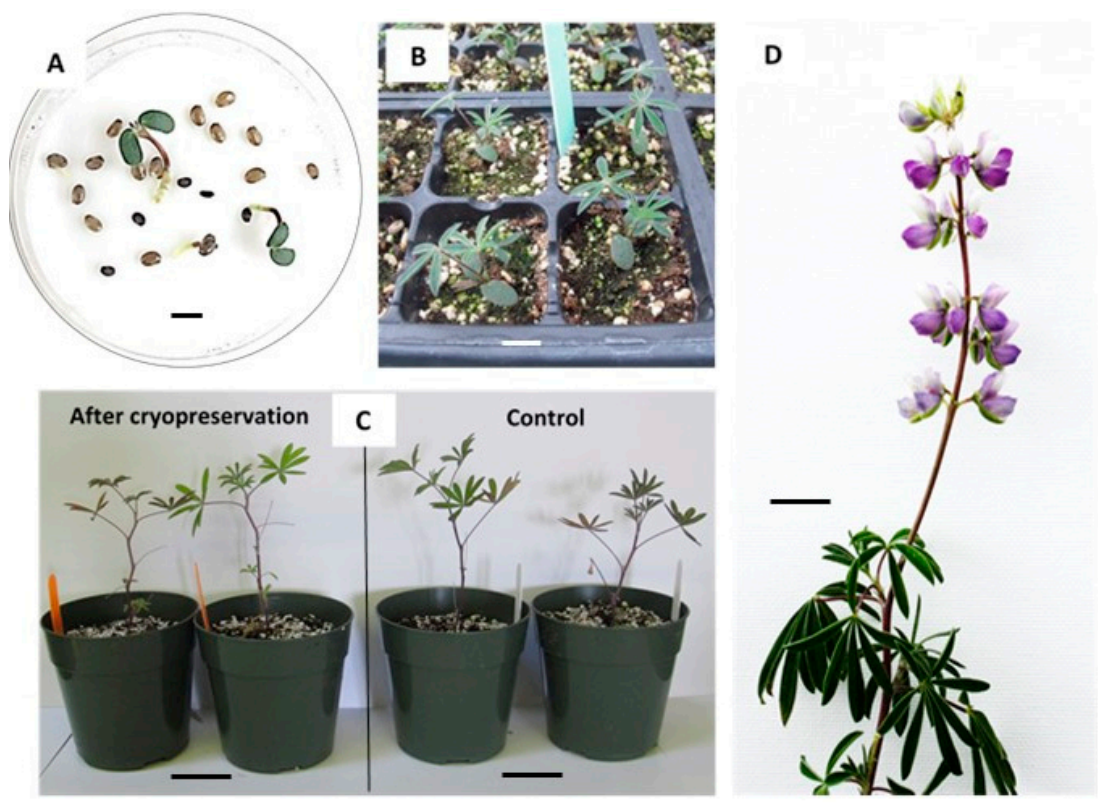

Figure 4. In Vitro germination of cryopreserved seeds and growth of Lupinus rivularis on filter paper $(\mathbf{A})$ bar $=1 \mathrm{~cm}$; and in the greenhouse after three months $(\mathbf{B})$ bar $=1 \mathrm{~cm}$; Seedlings developed from cryopreserved and non-cryopreserved (control) seeds in the greenhouse after six months, bar $=3 \mathrm{~cm}(\mathrm{C})$; and flowering observed in the greenhouse after nine months (D) bar $=3 \mathrm{~cm}$. 
Table 2. Morphological traits and chlorophyll content in leaves of plants developed in a greenhouse from control and cryopreserved seeds of two different lots.

\begin{tabular}{ccccccc}
\hline Seed Lot & Treatment & $\begin{array}{c}\text { Number of } \\
\text { Leaves }\end{array}$ & $\begin{array}{c}\text { Number of } \\
\text { Branches }\end{array}$ & $\begin{array}{c}\text { Length of the } \\
\text { Longest } \\
\text { Branch }(\mathbf{c m})\end{array}$ & $\begin{array}{c}\text { Number of } \\
\text { Flower Stalks }\end{array}$ & $\begin{array}{c}\text { Chlorophyll } \\
\text { Content } \\
\left(\mathbf{m g} / \mathbf{m}^{2}\right)\end{array}$ \\
\hline Lot 1 & Control & $5.8 \pm 0.32^{\mathrm{b}}$ & $5.9 \pm 0.4^{\mathrm{a}}$ & $21.1 \pm 1.4^{\mathrm{a}}$ & $1.4 \pm 0.2^{\mathrm{a}}$ & $454.2^{\mathrm{a}} \pm 7.7^{\mathrm{a}}$ \\
& Cryopreserved & $5.8 \pm 0.26^{\mathrm{b}}$ & $6.0 \pm 0.4^{\mathrm{a}}$ & $18.9 \pm 1.4^{\mathrm{a}}$ & $1.6 \pm 0.2^{\mathrm{a}}$ & $470.4 \pm 10.9^{\mathrm{a}}$ \\
\hline Lot 2 & Control & $8.0 \pm 0.5^{\mathrm{a}}$ & $5.6 \pm 0.7^{\mathrm{a}}$ & $18.4 \pm 2.5^{\mathrm{a}}$ & $1.0 \pm 0.0^{\mathrm{a}}$ & $451.9^{\mathrm{a}} \pm 11.2^{\mathrm{a}}$ \\
& Cryopreserved & $8.1 \pm 0.8^{\mathrm{a}}$ & $3.0 \pm 1.5^{\mathrm{b}}$ & $24.7 \pm 5.0^{\mathrm{a}}$ & $1.5^{\mathrm{a}} \pm 0.7^{\mathrm{a}}$ & $462.5 \pm 9.4^{\mathrm{a}}$ \\
\hline
\end{tabular}

Note: Data represents mean \pm standard error. Morphological traits were measured using 40 plants in each group. Chlorophyll content in leaves was estimated using four measurements from each of 10 plants per group. Means followed by different letters in columns are significantly different according to Tukey Test $(p<0.05)$.

\subsection{Cryopreservation of Apical Shoot Tips}

All shoot tips survived (100\%) step-wise cryoprotectant treatments of the dropletvitrification protocol without liquid nitrogen exposure. After cryopreservation, $62 \%$ of shoot tips survived and developed into normal healthy plants (Figure 2E,F) and could be further propagated using the micropropagation protocol described in this study to produce a large population of uniform plants. Plant regeneration from both control and cryopreserved shoot tips occurred directly without an intervening callus phase.

\section{Discussion}

\subsection{Seed Germination, Shoot Multiplication and Plantlet Development}

The main purpose of this study was to establish protocols for micropropagation and cryopreservation to preserve L. rivularis germplasm, an endangered species in Canada. Micropropagation and cryopreservation are key techniques which hold tremendous potential in the field of plant biodiversity conservation $[5,6]$. Mass propagation can be used as a means to generate a source of robust plants to replenish declining populations in their natural habitats. Similarly, cryopreservation plays an important role in ensuring the long-term security of the germplasm. We have developed and successfully applied a conservation approach CPR for saving and restoration of Canadian species at risk including Castilleja levisecta $[9,14]$ and Cirsium hillii [10]. Plants of C. levisecta and C. hillii after in vitro propagation and cryopreservation were re-introduced in their natural habitats where they showed normal growth, shoot and flower development over years [10]. In the present study, we applied the conservation approach to safeguard a genetic recourse of critically imperiled and endangered streambank lupine (L. rivularis). Existing strategies for recovery of streambank lupine have focused on mitigation of extinction threats to this species through preservation of natural habitats and the gene pool by maintaining pure populations. L. rivularis is known to hybridize with other lupine species in particular with invasive L. arboreus [1] and the growing interest in lupines as a food crop indicates that preserving a range of gene pools for this species may be agriculturally important. L. rivularis could also be of medicinal value as other lupine species have therapeutic properties, especially in diabetes therapy [26,27]. Similar to other Lupinus spp. grown as ornamentals and for forage [28,29], L. rivularis can be introduced as a new flowering plant (Figure 2D) in landscaping. Introduction of endangered species as cultivated crops for specific applications is likely to improve germplasm maintenance and conservation strategies.

Thidiazuron (TDZ) in low concentrations is often used to develop effective in vitro propagation systems through formation of multiple shoots on different types of explants such as cotyledons, nodal explants, embryonic axis, etc. [30-34]. TDZ was also shown to induce multiple shoot development from seeds germinating in vitro [35-38], with profound effect in regeneration of legumes [39]. Seeds of Pisum sativum cultured with $4 \mathrm{mg} / \mathrm{L} \mathrm{TDZ}$ for 12 weeks followed by 4 weeks on medium with $0.5 \mathrm{mg} / \mathrm{L}$ BA produced over 400 shoots per seedling [40]. In the present study, the shoots produced with 5-20 $\mu \mathrm{M}$ TDZ were abnormal and died during the next 3-4 passages on TDZ-free medium (data not shown). High con- 
centrations of TDZ or long exposure were reported to induce morphological, physiological, and cytogenetic abnormalities in many other species making plants incapable for further growth or multiplication [41]. Therefore, $1 \mu \mathrm{M}$ TDZ was selected as an optimum level for developing normal shoots from seeds of $L$. rivularis. The presence of TDZ in the medium did not affect germination which was relatively high in both seed lots. Similar observations have been recorded earlier for TDZ induced seed germination in several species including L. angustifolius and L. luteus [42]. Interestingly, seeds of lot 2 produced fewer shoots and their ability for multiple shoot formation was lower compared to that of seeds from lot 1 although they were one year younger. In wild species such differences in seed quality are frequent and may occur due to unfavorable environmental conditions during maturation process which also highlights the importance of testing seeds of multi-year generations in implementing conservation programs [43].

Results on shoot multiplication of L. rivularis are in line with data reported for forage lupine species. For example, Pniewski et al. developed in vitro propagation method for nine cultivars and breeding lines belonging to four crop lupine species following seed germination in vitro [20]. Significant differences in multiplication ratio calculated for 10 passages were observed between species and cultivars. The authors reported that low BA concentration $(0.05-0.25 \mathrm{mg} / \mathrm{L})$ was required for regeneration of normal plants. Micropropagation of L. angustifolius from segments of 3-day-old in vitro seedlings was accomplished successfully on MS medium with $2.25 \mu \mathrm{M}$ BA and $1.13 \mu \mathrm{M}$ kinetin. The epicotyl explants of L. montanus cultured on MS medium with $3.0 \mu \mathrm{M}$ IAA and $1.0 \mu \mathrm{M}$ BA produced optimum response for the number of shoots and their growth [44]. In the present study, apical, middle and basal stem segments of L. rivularis showed different responses in terms of number of new shoots and shoot length (Table 1). Literature describing the influence of explant position on the mother plant on micropropagation efficiency is scarce in lupines and in a large number of plant species. Interestingly, in contrast to our observations, Quercus robur explants from basal and apical regions demonstrated the lowest frequencies of shoot development and multiple shoot formation compared to nodal explants excised from the mid-stem positions [45]. Second node explants were found most viable and ready to proliferate in Psidium guajava [46] and first three apical nodes were preferable materials to initiate the culture of Corylus avellana [47]. These results are a reflection of the endogenous levels of phytohormones which often determine the requirements of the type and levels of exogenously applied growth regulators to achieve a desired morphogenetic response [48].

In vitro developed shoots were successfully rooted with the addition of an exogenously added auxin (20.0 $\mu \mathrm{M}$ IBA) and the plantlets survived the greenhouse transplant. The preconditioning of plantlets in the mist bed was necessary to reduce the shock of transferring plants from nearly $100 \%$ humidity in the culture vessels to the greenhouse. However, a large number of longer roots developed on IBA-containing medium along with mist bed conditioning ensured the development of robust plantlets that survived well in the greenhouse.

\subsection{Seed Cryopreservation and Its Effect on Plant Development}

Cryopreservation can provide viability insurance for the long-term, over 100 years, for the orthodox seeds $[49,50]$ and is worth testing for biobanking of a wide range of endemic and endangered wild species. For successful cryopreservation, orthodox seeds should be desiccated to a moisture content below the high moisture freezing limit [11]. In the case of $L$. rivularis, however, seed water content could not be determined due to the scarcity of available seeds and they were used directly to test the feasibility of cryopreservation. Germination of L. rivularis seeds in both growth chamber and in the greenhouse was not affected by LN exposure. This is in line with other studies on cryopreservation of orthodox seeds of wild species at risk [51-54]. Moreover, in some species, such as for example, Spanish endemics Helianthemum polygonoides and H. squamatum, cryopreservation contributed to dormancy breaking [55]. Among nine Indian medicinal plant species tested for seed response to cryopreservation, seeds of eight species germinated at levels compa- 
rable to desiccated control seeds [56]. In six Encholirium and two Dyckia species endemic to Brazil, seed germination ability after freezing in liquid nitrogen was higher than or similar to control seeds [57]. Out of eight endemic species of the Canary Islands tested for cryopreservation, seeds of seven species germinated at rates higher or similar to unfrozen control [58]. According to Coehlo et al., successful cryopreservation of orthodox seeds has been reported for at least 21 endemic plant species in the last decade [59]. In most of the reviewed studies, no loss in seed viability and no significant differences were observed for the germination rate between cryopreserved and non-cryopreserved seeds.

Plants developed from cryopreserved L. rivularis seeds were similar in morphology and growth characteristics to plants raised from control seeds. The only difference was observed in the number of branches in one seed lot which may be a result of origin and physiological differences in the population caused by environmental conditions of the habitat. Similar to our results, cryopreservation of seeds had no influence on protocorm growth and plant development in some tropical and terrestrial orchids [60,61]. In Solanum lycopersicum, a wild plant from Ecuador, fresh weight of plants developed from control and cryopreserved seeds were not statistically different [62]. The authors also recorded higher levels of peroxidase activities in leaves and decreased contents of chlorophylls of plants developed from cryopreserved seeds, which is in contrast to our observation of similar chlorophyll contents in leaves of plants from the cryopreserved and control treatments. Normal plant development and production of inflorescences in our study suggest that seed cryopreservation is an efficient method to conserve the genetic diversity of the existing L. rivularis populations. However, further study of the effects of longer exposure of seeds to liquid nitrogen may help in improving overall effectiveness of the cryopreservation process.

\subsection{Cryopreservation of Apical Shoot Tips}

In complement to seed cryo-storage, cryopreservation of shoot tips of in vitro plants can help conserving the gene pool of the existing plants and support their multiplication to replenish the dwindling populations $[63,64]$. The successful cryopreservation of shoot tips using modern methods, such as droplet-vitrification, depends on finding a balance between sufficient dehydration of the material in the concentrated cryoprotectant solutions and cytotoxic effect of these solutions [65]. Cryopreservation of plant vegetative parts is a complex, multi-stage procedure that requires optimization of a number of parameters such as temperature, duration of treatments, cryoprotectant solution concentration, pre and post culture conditions, and the method of cryopreservation for each plant species [66]. In the present study, we applied a different approach to cryopreservation of in vitro plant material which was developed and successfully tested earlier for a number of plant species $[14,67-70]$. In this approach, plant materials are classified into groups based on their sensitivity to chemical and osmotic stresses, with standard protocols proposed for each group [24,70]. Due to the lack of sufficient starting material, previously optimized standard protocol was tested for L. rivularis shoot tips based on their size and structural similarity to shoot tips of some other Canadian species studied previously [14,68]. As a result of this single trial, $62 \%$ of shoot tips survived cryopreservation and developed into normal plants that could be further propagated using the in vitro multiplication method developed in this study. Since micropropagation allows regeneration of a large number of plants, the number of cryopreserved samples can be increased easily to further enhance the ease and recovery of plants from the cryobank.

\section{Conclusions}

The CPR model offers an effective approach to safeguarding and replenishing the dwindling genetic resources of wild species at risk of extinction. In Vitro propagation technology allows multiplication of vigorous plants for redistribution while cryopreservation creates a long-term germplasm collection, serving as an ultimate back-up for an unfortunate scenario of the species becoming extinct in nature. In this study, we developed ex 
situ conservation approach for L. rivularis using in vitro technologies. In Vitro germinated seeds were induced to form multiple shoots which were further propagated and used to provide fresh shoot tips for cryopreservation with successful recovery of cryopreserved shoot tips into normal plants. Cryopreservation of seeds followed by germination in the growth chamber or in a greenhouse was also found to be an effective conservation option with no adverse effect on seed germination and plant development. Taken together, the in vitro propagation and conservation approaches developed in this study provide excellent opportunities for long-term preservation and restoration of L. rivularis, and possibly for many other species currently under threat of extinction. In Vitro multiplication methods developed in this study can also assist potential introduction of this species as a medicinal or ornamental plant.

Author Contributions: E.V.P., M.R.S., and P.K.S. were involved in the development of the hypotheses and experimental design. T.M. had provided the seeds for the experiments and contributed in interpretation of results. E.V.P. and M.R.S. conducted the majority of the experiments and the manuscript was developed by E.V.P. and M.R.S. All authors have read and agreed to the published version of the manuscript.

Funding: This research was funded by the Gosling Foundation, grant number 050294.

Data Availability Statement: No new data were created or analyzed in this study. Data sharing is not applicable to this article.

Acknowledgments: The authors gratefully acknowledge the financial support from the Gosling Foundation to the Gosling Research Institute of Plant Preservation (GRIPP).

Conflicts of Interest: The authors declare no conflict of interest.

\section{References}

1. Riggins, R.; Sholars, T. Lupinus. In The Jepson Manual: Higher Plants of California; University of California Press: Berkeley, CA, USA, 1993; pp. 622-636.

2. COSEWIC. COSEWIC Assessment and Status Report on the Streambank Lupine Lupinus rivularis in Canada; COSEWIC: Ottawa, ON, Canada, 2002.

3. Streambank Lupine Recovery Team. Recovery Plan for Streambank Lupine (Lupinus rivularis) in British Columbia; Government of Canada: Victoria, BC, Canada, 2014.

4. Environment and Climate Change Canada. In Recovery Strategy for the Streambank Lupine (Lupinus rivularis) in Canada; Environment and Climate Change Canada: Ottawa, ON, Canada, 2017.

5. Halmagyi, A.; Coste, A.; Jarda, L.; Butiuc-Keul, A.; Holobiuc, I.; Cristea, V. A safeguard measure of endemic and endangered plant species: Cryostorage of Dianthus taxa. Biodivers. Conserv. 2020, 29, 3445-3460. [CrossRef]

6. Pence, V.C.; Ballesteros, D.; Walters, C.; Reed, B.M.; Philpott, M.; Dixon, K.W.; Pritchard, H.W.; Culley, T.M.; Vanhove, A.-C. Cryobiotechnologies: Tools for expanding long-term ex situ conservation to all plant species. Biol. Conserv. 2020, $250,108736$. [CrossRef]

7. González-Benito, M.E.; Martin, C. In vitro preservation of Spanish biodiversity. In Vitr. Cell. Dev. Biol. Plant. 2010, 47, 46-54. [CrossRef]

8. Pence, V. In Vitro methods and cryopreservation: Tools for endangered exceptional Sspecies preservation and restoration. Acta Hortic. 2014, 73-79. [CrossRef]

9. Salama, A.; Shukla, M.R.; Popova, E.; Fisk, N.S.; Jones, M.P.; Saxena, P.K. In vitro propagation and reintroduction of golden paintbrush (Castilleja levisecta), a critically imperiled plant species. Can. J. Plant Sci. 2018, 98, 762-770. [CrossRef]

10. Sheikholeslami, B.; Shukla, M.; Turi, C.; Harpur, C.; Saxena, P.K. Saving threatened plant species: Reintroduction of Hill's thistle (Cirsium hillii (Canby) Fernald) to its natural habitat. PLoS ONE 2020, 15, e0231741. [CrossRef] [PubMed]

11. Pritchard, H.W. Cryopreservation of desiccation-tolerant seeds. Cryopreserv. Free. Protoc. Methods Mol. Biol. 2007, 368, 185-201. [CrossRef]

12. Uchendu, E.E.; Shukla, M.R.; Reed, B.M.; Saxena, P.K. Melatonin enhances the recovery of cryopreserved shoot tips of American elm (Ulmus americana L.). J. Pineal Res. 2013, 55, 435-442. [CrossRef] [PubMed]

13. Pence, V.C.; Philpott, M.; Culley, T.M.; Plair, B.; Yorke, S.R.; Lindsey, K.; Vanhove, A.-C.; Ballesteros, D. Survival and genetic stability of shoot tips of Hedeoma todsenii R.S.Irving after long-term cryostorage. In Vitr. Cell. Dev. Biol. Plant. 2017, 53, 328-338. [CrossRef]

14. Salama, A.; Popova, E.; Jones, M.P.; Shukla, M.R.; Fisk, N.S.; Saxena, P.K. Cryopreservation of the critically endangered golden paintbrush (Castilleja levisecta Greenm.): From nature to cryobank to nature. In Vitr. Cell. Dev. Biol. Plant. 2018, 54, 69-78. [CrossRef] 
15. Ciringer, T.; Martín, C.; Šajna, N.; Kaligarič, M.; Ambrožič-Dolinšek, J. Cryopreservation of an endangered Hladnikia pastinacifolia Rchb. by shoot tip encapsulation-dehydration and encapsulation-vitrification. In Vitr. Cell. Dev. Biol. Plant. 2018, 54, 565-575. [CrossRef]

16. Kew 2019. Royal Botanic Gardens Kew Seed Information Database (SID). Version 7.1. Available online: http://data.kew.org/sid/ (accessed on 18 September 2020).

17. Darris, D.; Young-Mathews, A. Plant Fact Sheet for Riverbank Lupine (Lupinus rivularis); USDA NRCs Plant Materials Center: Corvallis, OR, USA, 2012.

18. Costa, J.; Ricardo, C.P. Tunicamycin and swainsonine stimulate Lupinus albus L. root growth in vitro. Plant Sci. 1994, 101, 137-142. [CrossRef]

19. Borek, S.; Kalemba, E.M.; Pukacka, S.; Pietrowska-Borek, M.; Stawiński, S.; Ratajczak, L. Nitrate simultaneously enhances lipid and protein accumulation in developing yellow lupin cotyledons cultured in vitro, but not under field conditions. J. Plant Physiol. 2017, 216, 26-34. [CrossRef] [PubMed]

20. Pniewski, T.; Kapusta, J.; Legocki, A.B. In vitro micropropagation of four lupin species. Acta Physiol. Plant. 2002, 24, 417-424. [CrossRef]

21. Warren, R.; Vanderwal, J.; Price, J.C.; Welbergen, A.J.; Atkinson, I.; Ramirezvillegas, J.; Osborn, T.J.; Jarvis, A.; Shoo, L.P.; Williams, S.; et al. Quantifying the benefit of early climate change mitigation in avoiding biodiversity loss. Nat. Clim. Chang. 2013, 3, 678-682. [CrossRef]

22. Murashige, T.; Skoog, F. A revised medium for rapid growth and bioassays with tobacco tissue cultures. Physiol. Plant 1962, 15, 473-497. [CrossRef]

23. Gitelson, A.; Buschmann, C.; Lichtenthaler, H.K. The chlorophyll fluorescence ratio F735/F700 as an accurate measure of the chlorophyll content in plants. Remote. Sens. Environ. 1999, 69, 296-302. [CrossRef]

24. Popova, E.; Shukla, M.; Kim, H.H.; Saxena, P.K. Plant cryopreservation for biotechnology and breeding. Adv. Plant Breed. Strateg. Breed. Biotechnol. Mol. Tools 2015, 63-93. [CrossRef]

25. Kim, H.-H.; Lee, Y.-G.; Shin, D.-J.; Ko, H.-C.; Gwag, J.-G.; Cho, E.-G.; Engelmann, F. Development of alternative plant vitrification solutions in droplet-vitrification procedures. CryoLetters 2009, 30, 320-334. [CrossRef]

26. Knecht, K.T.; Nguyen, H.; Auker, A.D.; Kinder, D.H. Effects of extracts of lupine seed on blood glucose levels in glucose resistant mice. J. Herb. Pharmacother. 2006, 6, 89-104. [CrossRef]

27. Kinder, D.H.; Knecht, K.T. Lupine (Lupinus caudatus L., Lupinus albus L.) Seeds: History of use, use as an antihyperglycemic medicinal, and use as a food. Nuts Seeds Health Dis. Prev. 2011, 711-716. [CrossRef]

28. Elmer, W.H.; Yang, H.A.; Sweetingham, M.W. Characterization of Colletotrichum gloeosporioides isolates from ornamental lupines in connecticut. Plant Dis. 2001, 85, 216-219. [CrossRef] [PubMed]

29. Didur, I.M.; Prokopchuk, V.M.; Pantsyreva, H.V. Investigation of biomorphological and decorative characteristics of ornamental species of the genus Lupinus L. Ukr. J. Ecol. 2019, 9, 287-290. [CrossRef]

30. Murthy, B.N.S.; Murch, S.J.; Saxena, P.K. Thidiazuron: A potent regulator of in vitro plant morphogenesis. In Vitr. Cell. Dev. Biol. Plant. 1998, 34, 267-275. [CrossRef]

31. Singh, R.; Jat, R.S.; Sahoo, P.D.; Srinivasan, R. Thidiazuron induced multiple shoot formation in chickpea (Cicer arietinum L). J. Plant Biochem. Biotechnol. 2002, 11, 129-131. [CrossRef]

32. Yucesan, B.; Turker, A.U.; Gurel, E. TDZ-induced high frequency plant regeneration through multiple shoot formation in witloof chicory (Cichorium intybus L.). Plant Cell Tissue Organ Cult. 2007, 91, 243-250. [CrossRef]

33. Chhabra, G.; Chaudhary, D.; Varma, M.; Sainger, M.; Jaiwal, P.K. TDZ-induced direct shoot organogenesis and somatic embryogenesis on cotyledonary node explants of lentil (Lens culinaris Medik). Physiol. Mol. Biol. Plants 2008, 14, 347-353. [CrossRef]

34. Padmanabhan, P.; Murch, S.J.; Sullivan, J.A.; Saxena, P.K. Development of an efficient protocol for high frequency in vitro regeneration of a horticultural plant Primulina tamiana (B.L. Burtt) Mich. Möller \& A. Webber. Can. J. Plant Sci. 2014, 94, 1281-1287. [CrossRef]

35. Malik, K.; Saxena, P. Thidiazuron induces high-frequency shoot regeneration in intact seedlings of pea (Pisum sativum), chickpea (Cicer arietinum) and lentil (Lens culinaris). Funct. Plant Biol. 1992, 19, 731. [CrossRef]

36. Murthy, B.N.S.; Murch, S.J.; Saxena, P.K. Thidiazuron-induced somatic embryogenesis in intact seedlings of peanut (Arachis hypogaea): Endogenous growth regulator levels and significance of cotyledons. Physiol. Plant. 1995, 94, 268-276. [CrossRef]

37. Ye, G.; McNeil, D.L.; Conner, A.J.; Hill, G.D. Multiple shoot formation in lentil (Lens culinaris) seeds. N. Z. J. Crop. Hortic. Sci. 2010, 30, 1-8. [CrossRef]

38. Monthony, A.S.; Baethke, K.; Erland, L.A.E.; Murch, S.J. Tools for conservation of Balsamorhiza deltoidea and Balsamorhiza sagittata: Karrikin and thidiazuron-induced growth. In Vitr. Cell. Dev. Biol. Plant. 2020, 56, 398-406. [CrossRef]

39. Mundhara, R.; Rashid, A. Recalcitrant grain legume Vigna radiata, mung bean, made to regenerate on change of hormonal and cultural conditions. Plant Cell Tissue Organ Cult. 2006, 85, 265-270. [CrossRef]

40. Zhihui, S.; Tzitzikas, M.; Raemakers, C.J.J.M.; Zhengqiang, M.; Visser, R. Effect of TDZ on plant regeneration from mature seeds in pea (Pisum sativum). In Vitr. Cell. Dev. Biol. Plant. 2009, 45, 776-782. [CrossRef]

41. Dewir, Y.H.; Naidoo, Y.; Da Silva, J.A.T. Thidiazuron-induced abnormalities in plant tissue cultures. Plant Cell Rep. 2018, 37, 1451-1470. [CrossRef] 
42. Surma, M.; Adamski, T.; Święcicki, W.; Barzyk, P.; Kaczmarek, Z.; Kuczyńska, A.; Krystkowiak, K.; Mikołajczak, K.; Ogrodowicz, P. Preliminary results of in vitro culture of pea and lupin embryos for the reduction of generation cycles in single seed descent technique. Acta Soc. Bot. Pol. 2013, 82, 231-236. [CrossRef]

43. Daws, M.I.; Pritchard, H.W. The development and limits of freezing tolerance in Acer pseudoplatanus fruits across Europe is dependent on provenance. CryoLetters 2008, 29, 189-198.

44. Ramírez-González, G.; Rodríguez-de, J.L.L.O.; Arreola-Ávila, J.G.; Álvarez-Moctezuma, J.G. Morphogenic responses of three explants of Lupinus montanus (H.B.K.) cultured in vitro. Rev. Chapingo Ser. Cienc. For. Ambient. 2015, 17-27. [CrossRef]

45. Puddephat, I.; Alderson, P.; Wright, N. Influence of explant source, plant growth regulators and culture environment on culture initiation and establishment of Quercus robur L. in vitro. J. Exp. Bot. 1997, 48, 951-962. [CrossRef]

46. Shekafandeh, A.; Khosh-Khui, M. Effects of bud position and culture medium on shoot proliferation from nodal culture of two mature guava cultivars. Asian J. Plant Sci. 2008, 7, 177-182. [CrossRef]

47. Hand, C.R.; Wada, N.; Stockwell, V.; Reed, B.M. Node position influences viability and contamination in hazelnut shoot explants. In Vitr. Cell. Dev. Biol. Plant. 2016, 52, 580-589. [CrossRef]

48. Shukla, M.R.; Jones, A.M.P.; Sullivan, J.A.; Liu, C.; Gosling, S.; Saxena, P.K. In vitro conservation of American elm (Ulmus americana): Potential role of auxin metabolism in sustained plant proliferation. Can. J. For. Res. 2012, 42, 686-697. [CrossRef]

49. Walters, C.; Wheeler, L.; Stanwood, P.C. Longevity of cryogenically stored seeds. Cryobiology 2004, 48, 229-244. [CrossRef] [PubMed]

50. Pritchard, H.W.; Nadarajan, J. Cryopreservation of orthodox (desiccation tolerant) Seeds. Plant Cryopreserv. A Pract. Guid. 2008. [CrossRef]

51. Pence, V.C. Cryopreservation of seeds of Ohio native plants and related species. Seed Sci. Technol. 1991, 19, $235-251$.

52. Tikhonova, V.L. Long-term storage of seeds. Russ. J. Plant Physiol. 1999, 46, 400-408.

53. Kholina, A.B.; Voronkova, N.M. Conserving the gene pool of Far Eastern plants by means of seed cryopreservation. Izv. Akad. Nauk. Seriia Boil. 2008, 35, 262-269. [CrossRef]

54. Popova, E.V.; Kim, D.H.; Han, S.H.; Moltchanova, E.; Pritchard, H.W.; Hong, Y.P. Systematic overestimation of Salicaceae seed survival using radicle emergence in response to drying and storage: Implications for ex situ seed banking. Acta Physiol. Plant. 2013, 35, 3015-3025. [CrossRef]

55. Gonzalez-Benito, M.E.; Iriondo, J.M.; Pérez-García, F. Seed cryopreservation: An alternative method for the conservation of Spanish endemics. Seed Sci. Technol. 1998, 26, 257-262.

56. Decruse, S.W.; Seeni, S.; Pushpangadan, P. Effects of cryopreservation on seed germination of selected rare medicinal plants of India. Seed Sci. Technol. 1999, 27, 501-505.

57. Tarré, E.; Pires, B.B.M.; Guimarães, A.P.M.; Carneiro, L.A.; Forzza, R.C.; Mansur, E. Germinability after desiccation, storage and cryopreservation of seeds from endemic Encholirium Mart. ex Schult. \& Schult. f. and Dyckia Schult. \& Schult. f. species (Bromeliaceae). Acta Bot. Bras. 2007, 21, 777-783. [CrossRef]

58. Pérez-García, F. Effect of cryopreservation, gibberellic acid and mechanical scarification on the seed germination of eight endemic species from the Canary Islands. Seed Sci. Technol. 2008, 36, 237-242. [CrossRef]

59. Coelho, N.; Gonçalves, S.; Romano, A. Endemic plant species conservation: Biotechnological approaches. Plants 2020, 9, 345. [CrossRef] [PubMed]

60. Popova, E.V.; Nikishina, T.V.; Kolomeitseva, G.L.; Popov, A.S. The Effect of seed cryopreservation on the development of protocorms by the hybrid orchid Bratonia. Russ. J. Plant Physiol. 2003, 50, 672-677. [CrossRef]

61. Nikishina, T.V.; Popova, E.V.; Vakhrameeva, M.G.; Varlygina, T.I.; Kolomeitseva, G.L.; Burov, A.V.; Popovich, E.A.; Shirokov, A.I.; Shumilov, V.Y.; Popov, A.S. Cryopreservation of seeds and protocorms of rare temperate orchids. Russ. J. Plant Physiol. 2007, 54, 121-127. [CrossRef]

62. Zevallos, B.; Cejas, I.; Rodríguez, R.C.; Yabor, L.; Aragón, C.; González, J. Biochemical characterization of Ecuadorian wild Solanum lycopersicum Mill. plants produced from non-cryopreserved and cryopreserved seeds. CryoLetters 2016, 37, 413-421.

63. Whiteley, S.E.; Bunn, E.; Menon, A.; Mancera, R.L.; Turner, S.R. Ex situ conservation of the endangered species Androcalva perlaria (Malvaceae) by micropropagation and cryopreservation. Plant Cell Tissue Organ Cult. 2016, 125, 341-352. [CrossRef]

64. Streczynski, R.; Clark, H.; Whelehan, L.M.; Ang, S.-T.; Hardstaff, L.K.; Funnekotter, B.; Bunn, E.; Offord, C.A.; Sommerville, K.D.; Mancera, R.L. Current issues in plant cryopreservation and importance for ex situ conservation of threatened Australian native species. Aust. J. Bot. 2019, 67, 1-15. [CrossRef]

65. Sakai, A.; Engelmann, F. Vitrification, encapsulation-vitrification and droplet-vitrification: A review. CryoLetters 2007, $28,151-172$.

66. Wang, M.-R.; Lambardi, M.; Engelmann, F.; Pathirana, R.; Panis, B.; Volk, G.M.; Wang, Q.-C. Advances in cryopreservation of in vitro-derived propagules: Technologies and explant sources. Plant Cell Tissue Organ Cult. 2020, 1-14. [CrossRef]

67. Kim, H.-H.; Lee, Y.G.; Park, S.U.; Lee, S.C.; Baek, H.J.; Cho, E.G.; Engelmann, F. Development of alternative loading solutions in droplet-vitrification procedures. CryoLetters 2009, 30, 291-299. [PubMed]

68. Rathwell, R.; Popova, E.; Shukla, M.R.; Saxena, P.K. Development of cryopreservation methods for cherry birch (Betula lenta L.), an endangered tree species in Canada. Can. J. For. Res. 2016, 46, 1284-1292. [CrossRef]

69. Choi, C.H.; Popova, E.; Lee, H.; Park, S.U.; Ku, J.; Kang, J.H.; Kim, H.H. Cryopreservation of endangered wild Species, Aster altaicus var. uchiyamae Kitam, using droplet-vitrification procedure. CryoLetters 2019, 40, 113-122. [PubMed]

70. Yang, X.; Popova, E.; Shukla, M.R.; Saxena, P.K. Root cryopreservation to biobank medicinal plants: A case study for Hypericum perforatum L. In Vitr. Cell. Dev. Biol. Plant. 2019, 55, 392-402. [CrossRef] 